\title{
An international comparison of journal publishing and citing behaviours ${ }^{1}$
}

\author{
Fereshteh Didegah ${ }^{1}$, Mike Thelwall ${ }^{1}$, Ali Gazni ${ }^{2}$, \\ ${ }^{1}$ Statistical Cybermetrics Research Group, School of Technology, University of Wolverhampton, Wulfruna Street, \\ Wolverhampton WV1 1LY, UK \\ ${ }^{2}$ Research Affairs of ISC, Shiraz, Iran
}

\begin{abstract}
The relationship between researchers' publishing and citing behaviours has received little examination despite its potential importance in scholarly communication, particularly at an international level. To remedy this we studied documents and their references indexed in Thomson Reuters's Web of Science (WoS) in the period 2000-2009 to compare journal publishing behaviours against journal citing behaviours across the world. The results reveal that most publications in, and citations to, all five quality based strata of journals examined come from scientifically and economically advanced countries. Nevertheless, in proportion to their total number of citations given to WoS journals, it seems that less developed countries cite high-quality journals at the same rate as developed countries and so the poorer publishing of less developed countries does not seem to be due to a lack of access to top journals. Moreover, examining the publishing and citing trends of countries revealed a decreasing rate of high-income and Scientifically Advanced Countries (SACs) publications in, and citations to, all quality ranges of journals in comparison to the increasing rate of publications and citations of other groups. Finally, research cooperation between developed and less developed countries seems to positively influence the publishing behaviour of the latter as their publications coauthored with developed countries were published more often in top journals.
\end{abstract}

Keywords: Publishing behaviour, Citing behaviour, Research collaboration.

\section{Introduction}

Journal prestige is an important element in the academic environment and influences the reputation of authors and affiliated institutions (Shichor, O'Brien, \& Decker, 1981). For a long time, one way to assess the quality of a paper has been by the quality and prestige of the journal in which it was published (Cheung, 2009; Yue, 2004; Martin, 1996; Miller \& Dodge, 1979; Ravetz, 1971). It seems the quality of references in a paper positively influences its visibility and impact (Boyack \& Klavans, 2005; Lancho-Barrantes, Guerrero-Bote, \& MoyaAnegon, 2010; Bornmann, Schier, Marx, \& Daniel, 2011) and hence it may be that lack of access to high quality journals prevents developing countries' researchers from producing high quality successful publications. Developed countries publish the majority of their papers in leading journals, with few papers originating from less developed countries (Mahawar, Malviya \& Kumar, 2006; Boldt, Maleck \& Koetter, 1999; Elster \& Chen, 1994). Some studies have tried to identify the reasons behind this. Cheung (2009) raises the issue of cultural-geographical bias amongst reviewers, but also finds that replication of previously published experiments, poor design and poor grammar (see also Rohra, 2011) is more common from researchers in less developed countries. These may be reasons why they are rejected by reviewers of international leading journals. Another reason why international

1 Didegah, F., Thelwall, M. \& Gazni, A. (2012). An international comparison of journal publishing and citing behaviours, Journal of Informetrics 6(4), 516-531. ( ) copyright 2012 Elsevier, Inc. 
journals may refuse to publish articles from developing countries could be that their readers are mostly from developed countries and desire to read articles pertinent to their own countries (Smith, 2002).

Despite publications from less developed countries not being widely published in highquality journals, do researchers in less developed countries cite papers published in the top journals of their own fields? To the best of our knowledge, no study has addressed this issue.

\section{Literature Review}

The objective of this study is to examine national journal publishing and citing behaviours. The journal impact factor is a widely used indicator of journal quality and prestige. Selgen (1997) argues that while peer review is a good indicator of quality, the impact factor is questionable, because it is not representative of all articles in a journal. Sometimes, a few papers in a journal receive a significant number of citations while the rest are uncited; although the impact factor of this journal may be high it does not truly represent the impact of individual articles. Peer review is the best measure of quality (Kostoff, 1997) but it is not perfect because it lacks reliability and has bias resulting from invalid and unreliable peerreviews, especially when the reviewees have chosen the reviewers themselves (Marsh, Jayasinghe, \& Bond, 2008). Garfield (1999) also states that "the Impact Factor is not as perfect tool to measure the quality of articles but there is nothing better". Some studies have critically analysed the impact factor and some have tried to normalize it by introducing an alternative measure of impact (Yanovski, 1981; Hansson, 1995; Moed \& Leeuwen, 1996; Moed, Leeuwen, \& Reedijk, 1996; 1999; Buela-Casal, 2004). In a detailed discussion of the potential and limitations of the journal impact factor, Glänzel and Moed (2002) claim that the strengths of this indicator include intelligibility, stability and reproducibility and argue that its 'uninformed use' is a flaw in practice. They also claim that there are several methodological limitations, such as field based and document type based biases. They also discuss some other journal citation measures aimed at correcting the journal impact factor's methodological flaws. Empirical studies addressing the question of the impact factor as a measure of quality are scarce. Surveying physicians to rate the quality of journals, the validity of the impact factor as an indicator of quality for General Medicine was examined and revealed that it may be a credible measure (Saha, Saint, \& Christakis, 2003). But, as many studies have confirmed, it cannot be a reasonable indicator of quality for an individual article (Seglen, 1997a; 1997b; 1997c; 1998; Garfield, 1998; Whitehouse, 2001; Kaltenborn \& Kuhn, 2004; Gracza \& Somoskovi, 2007). Campbell (2008) declares that the journal impact factor is suitable to measure impact at national and institutional levels but not at the individual level. $\mathrm{He}$ asserts that "citation statistics of large numbers of individual papers can reflect the impact of contributions at the institutional or national level" but is in doubt about individual papers and believes there are other more certain methods to measure the impact of an individual paper. In the current study the journal impact factor is used as an indicator of quality at national level despite its acknowledged limitations.

\section{Journal publishing behaviour}

Journal publishing behaviour and preferences for publishing in leading journals have been examined at different individual (Gordon, 1984; Luukkonen, 1992; Cheung, 2008), institutional (Bairam, 1994; Kocher, \& Sutter, 2001) and national levels. The contribution of countries or groups of countries to journals or conferences has been explored since 1980s (Schubert, Glänzel, \& Braun, 1989; Braun, Glänzel, \& Schubert, 1985; Schubert, Zsindely, \& Braun, 1983). Some studies have investigated country distributions of publications in a few high-impact journals; most have been carried out on specific fields of science and reported that most papers in high-quality journals come from researchers in the U.S. and U.K., with few from developing countries (Elliott, Greenaway, \& Sapsford, 1998; Black \& Davies, 
1999; Boldt, Maleck \& Koetter, 1999; Carnegie \& Potter, 2000; Patel \& Sumathipala, 2001; Jones \& Roberts, 2005; Mahawar, Malviya, \& Kumar, 2006; Cheung, 2009). Indeed, the chance of being accepted in an American journal is lower for submissions from countries other than the U.S. (Elster and Chen, 1994) and also the acceptance rate of papers from highincome countries is about five times greater than that of papers from low- and middle-income countries (Singh, 2006). Developed countries are the main readers of international journals and journal editorial boards are attempting to attract a wide range of readers (Smith, 2002). From an online survey of corresponding authors in Pharmacology, the biased attitude of editors and reviewers, followed by scientists' poor writing skills were found to be the main obstacles to publishing papers from less developed countries in international journals (Rohra, 2011). The same results were claimed by Cheung (2009).

Different factors may affect authors' publishing behaviour, one of which could be scientific collaboration. Many studies have emphasized the positive impacts of international collaboration mainly on the rise of the citation impact of internationally co-authored papers. It has been found that collaboration, in particular international collaboration, can also affect reference behaviour due to wider access to sources that a number of authors together collectively have. In addition, international collaboration may raise the equality amongst contributing nations in citation impact (Persson, Glänzel, \& Danell, 2004). Researchers have a variety of motivations for collaboration, such as to access more resources and equipment, to get funds, or to speed their research process and enhance productivity (Beaver, 2001) but as Cronin (2001) argues, the degree of authors' contributions to a paper may vary and all authors do not necessarily need to contribute in writing the paper. Wagner, Brahmakulam, Jackson, Wong, \& Yoda (2001) found that scientific collaboration helps developing countries to take part in global science. They mentioned some factors motivating researchers across developing countries to collaborate with researchers in developed countries including using their expertise, solving a global issue and equipment sharing. But no study has shown the effect of collaboration on publishing behaviour of researchers in less developed countries and the possibility of getting published in high impact journals.

\section{Journal citing behaviour and motivations}

Citation analysis studies the relationships between cited and citing works (Smith, 1981) and consists of a variety of ways to analyse cited works (Moed, 2005). Most citation analysis studies examined quantitative aspects of citations, like language, source type and year of publication, and a few dealt with the impact factor of cited journals as an indicator of quality.

Different studies have been conducted to find out the citation behaviour and motivations of authors. Some have tried to identify the impact of publication place on authors' citation behaviour. In Medical research, Campbell (1990) showed that US and UK researchers are more likely to cite publications produced in their own countries. It seems that researchers are more likely to cite national materials when publishing in national journals than in international journals (Lancaster, Lee \& Diluvio, 1990; Kim, 2002). Others have examined the references of a collection of papers in particular fields and tried to identify which countries they have targeted (Rabkin \& Inhaber, 1979; Faulkner, 1981; Velho and Krige, 1984). For example, Velho and Krige (1984) found that Brazilian agricultural researchers widely cite research conducted in advanced countries.

To sum up, as many previous studies of publishing behaviour have targeted the publishing behaviour of researchers of a particular domain or region in leading journals, no large-scale analyses that examine publishing behaviour differences across some developed and less developed groups of countries in a range of low- to high-quality journals have confirmed the universality of the phenomena identified. Furthermore, no study of scientific 
collaboration has focused on the impact of collaboration on the publishing behaviour of researchers in less developed countries; the present work aims to address these demands.

As reviewed above, researchers in certain less developed countries tend more to cite research conducted in advanced countries, but no study has examined journal citing behaviour of researchers across all domains and all countries and moreover, no comparison between countries' publishing and citing behaviour has been made.

Therefore to fill these gaps, the current study seeks to answer a number of questions:

- Are most publications in high-quality journals from researchers in developed countries?

- Are developed countries the main citers of all high-quality journals?

- Are less developed countries catching up or falling behind in publishing and citing behaviours?

- Does collaboration between less developed countries and developed countries help the former to publish in higher quality journals? Which groups are dominant in collaboration and are the publishing and citing patterns influenced by the behaviour of the dominant groups?

\section{Methodology}

We analysed publications and references to identify patterns of publishing and citing at the macro level during the period 2000-2009. This period was chosen as it is recent and comprises a reasonable number of years to make comparisons from. We utilized the citation products of Thomson Reuters (formerly ISI) to conduct the research. Scopus and Google Scholar are two other well-known citation databases but Moed (2005) argued that ISI products comprise the most important journals, although not all journals over the world. Both editions (Science and Social Science) of Journal Citation Reports (JCR) (from Thomson Reuters) were utilized to classify journals according to their impact factor. The journal impact factor is an indicator of quality widely used by academicians around the world (Brody \& Foster, 1995; Ohniwaa, Denawaa, Kudob, Nakamurab, \& Takeyasua, 2004; Kurmis \& Kurmis, 2006). JCR is the only system which includes journal impact factors for 2000-2009.

To assign a subject field to each journal in the set, the Science Watch ${ }^{2}$ website containing a list of JCR journals (continually updated) was used. The journals in this list have been categorized under 22 subject fields offered by Essential Science Indicators (ESI). We matched the Science Watch journals' list and the JCR journals based on the abbreviated titles of the journals to identify their fields.

To answer the research questions, JCR journals were grouped into different percentile ranges by IF and ESI fields. The ranges were derived from the Baseline Table of ESI, another Thomson Reuters product. This percentile table is divided into five sections for the 22 ESI fields. Therefore, according to their impact factors, journals in each field and each year were categorized into different percentiles from a range of lower-quality ${ }^{3}$ to high-quality journals: the top $1 \%, 1 \%-10 \%, 10 \%-20 \%, 20 \%-50 \%$ and 50\%-100\%. For example, the highest average impact factor belongs to the first group (the top 1\%); this group of 878 journals published

\footnotetext{
${ }^{2}$ www.ScienceWatch.com

${ }^{3}$ As all Thomson Reuters journals are the world's elite, hard to assume that any low-quality journal is indexed there. So, to differentiate between journals with lowest IF and those with higher IF, we call the former lowerquality journals.
} 
256,512 documents with an average of 33 citations per paper (Table 1). Information extracted and analysed for a total of 76,781 journals from 2000 to 2009 included abbreviated name, JCR year, impact factor, number of articles, total cites, subject field, percentile range and country of publication. To determine the high-impact journals of a single subject field in each year, a descending list of journals based on their impact factors was created. Based on the number of journals per year and per subject, journal percentiles were calculated out of the total number of journals. It should be noted that there is no overlap between the percentiles.

We next extracted WoS documents for the period 2000-2009. Particularly to answer the first question, document affiliation fields were examined and the documents were categorized by country into two scientific and economic classifications. Abbreviated titles of JCR journals were then matched with abbreviated titles of journals in WoS from the WoS J9 field. Some JCR journals could not be matched with WoS data. To tackle this problem, we matched journal ISSNs instead, finding many additional matches.

Regarding the number of authors, publications often have one or more affiliations and each affiliation normally contains a country name. A matrix was created encapsulating all necessary information to detect country publishing behaviour and finally the total number of papers affiliated by each country in each percentile was aggregated and the publishing behaviour of countries was determined.

To answer the second question, about 97,000,000 citations were assigned to cited WoS journals. A number of references were not matched to any record across the database and were lost as the cited documents were assumed to be mainly not indexed in the Thomson Reuters databases. A matrix containing journals of the references with their percentiles and publishing country or countries was created. Another matrix comprised of collaboration groups and journal percentiles was also constructed to answer the third research question. The share of groups of countries in collaboration with each other was calculated at the level of authors (Figure 1).

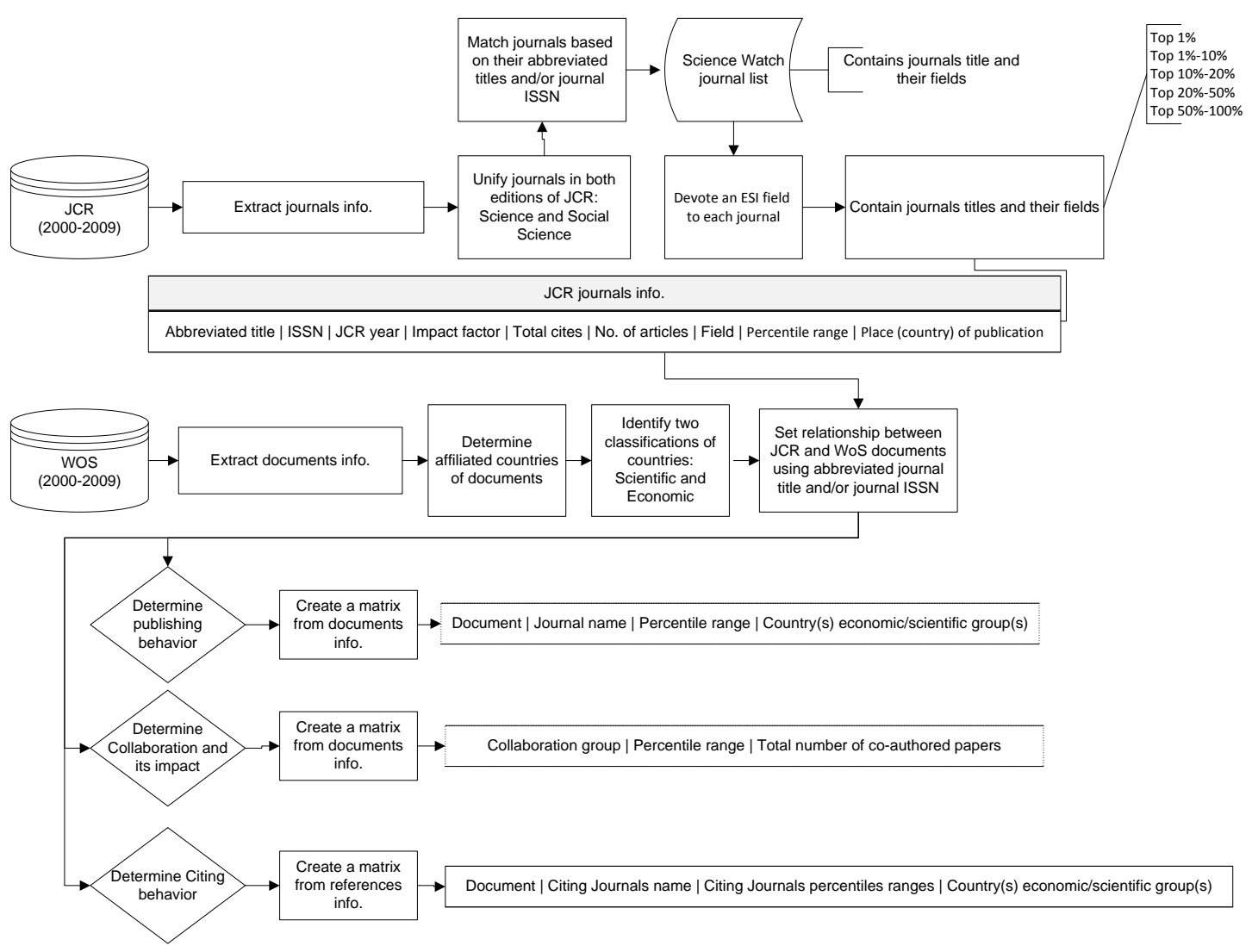

Figure 1. An overview of the data analysis process 
Table 1. Different features of journals at different levels of quality

\begin{tabular}{|c|c|c|c|c|c|c|c|c|}
\hline 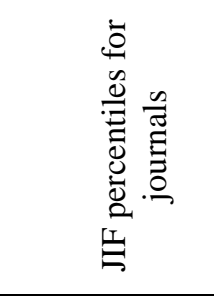 & 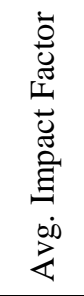 & 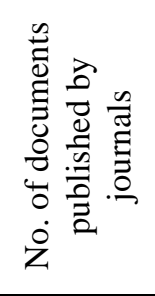 & 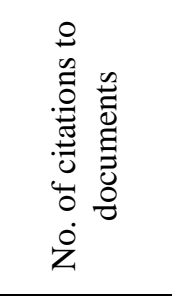 & 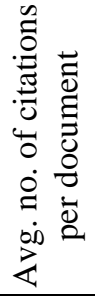 & 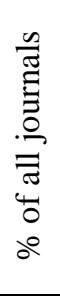 &  &  & 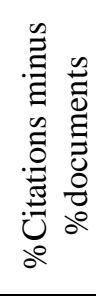 \\
\hline Top $1 \%$ & 14.4 & 256512 & 8398605 & 32.74 & 1 & 2.16 & 7.8 & 5.64 \\
\hline Top $1 \%-10 \%$ & 4.59 & 2545570 & 40472385 & 15.9 & 9 & 21.4 & 37.57 & 16.17 \\
\hline Top 10\%-20\% & 2.5 & 2055263 & 21969387 & 10.69 & 10 & 17.28 & 20.39 & 3.12 \\
\hline Top 20\%-50\% & 1.49 & 3471172 & 25699005 & 7.4 & 30 & 29.18 & 23.86 & -5.32 \\
\hline $50 \%-100 \%$ & 0.57 & 3568806 & 11187466 & 3.13 & 50 & 30 & 10.39 & -19.61 \\
\hline SUM & & 11897323 & 107726848 & & & & & \\
\hline
\end{tabular}

\section{WOS Data}

Given that articles and conference proceedings have similar citation behaviours (the average normalized citations ${ }^{4}$ for articles count for 1.29 and for conference proceedings for 1.03) and also are the main types of scientific literature, only these two types of documents were taken into account. Reviews were not considered as they are typically cited far more than other types of documents (Amin \& Mabe, 2000). All three indices (Arts \& Humanities Citation Index, Science Citation Index Expanded and Social Sciences Citation Index) were also considered. This study processed 11,897,323 WoS documents and about 97,000,000 references from 2000 to 2009.

\section{Categorizing countries}

Two approaches, scientific and economic, were used to categorize the countries of the world. Based on the rate of scientific development, Wagner, Brahmakulam, Jackson, Wong, \& Yoda (2001) classified countries into four groups including Scientifically Advanced Countries (SAC) comprising 22 countries like the USA and UK, Scientifically Proficient Countries (SPC) comprising 24 countries like Spain and Brazil, Scientifically Developing Countries (SDC) comprising 24 countries like Turkey and Iran and Scientifically Lagging Countries (SLC) comprising 80 countries like Thailand and Tajikistan. This approach was adopted in the current paper, although it is ten years old. Wagner, Brahmakulam, Jackson, Wong, \& Yoda (2001) classified 150 countries of the world; the omission of some countries is a limitation for the current study. Economically, countries were also categorized into four groups, as recently classified by the World Bank: high income comprising 70 countries like USA and UK, upper middle income comprising 54 countries like China and Algeria, lower middle income comprising 56 countries India and Iraq, and low income comprising 35

\footnotetext{
4 "Normalized citations" means the number of citations normalized by related subject field and published year.
} 
countries like Afghanistan and Ethiopia (The World Bank ${ }^{5}$, 2011). In a comparison of the two scientific and economic groups of countries we found classification differences. For example, almost all SACs are classified as high income countries but the reverse is not true. From a population statistics perspective in 2009, SPCs and upper middle income countries have the largest populations (Table 2).

Table 2. Total population of scientific and economic groups

\begin{tabular}{clccccc}
\hline Rank & Economic groups & $\begin{array}{c}\text { Total } \\
\text { population in } \\
\mathbf{2 0 0 9}\end{array}$ & $\begin{array}{c}\text { \% of world } \\
\text { population }\end{array}$ & $\begin{array}{c}\text { Scientific } \\
\text { groups }\end{array}$ & $\begin{array}{c}\text { Total } \\
\text { population in } \\
\mathbf{2 0 0 9}\end{array}$ & $\begin{array}{c}\text { \% of world } \\
\text { population }\end{array}$ \\
\hline 1 & Upper middle income & $2,435,250,358$ & 36 & SPCs & $2,986,983,562$ & 44.3 \\
2 & Lower middle income & $2,428,089,995$ & 35.9 & SLCs & $1,688,918,222$ & 25.1 \\
3 & High income & $1,120,454,524$ & 16.6 & SACs & $1,098,687,219$ & 16.3 \\
4 & Low income & $779,877,024$ & 11.5 & SDCs & $964,611,743$ & 14.3 \\
\hline & World & $6,763,671,901$ & 100 & World & $6,739,200,746$ & 100 \\
\hline
\end{tabular}

Source: The World Bank (2011). Total population. Available at: http://data.worldbank.org/indicator/SP.POP.TOTL.

\section{Results}

\section{Publishing behaviour by economic group}

Figure 2 shows the percentage of publications that each group of countries has published in the top $1 \%$ of journals. As can be seen, in all years examined more than $88 \%$ of publications in the top $1 \%$ of journals are from high-income countries whereas only $3-8 \%$ belong to upper-middle income countries, less than $3 \%$ to lower-middle income countries and less than $1 \%$ to low-income countries (See Table 3).

In all five journal percentile groups, a majority of publications belong to high-income countries. It should be noted that high-income publications average $71 \%$ in the last $50 \%$ of journals and $93 \%$ in the top $1 \%$ of journals. Low-income countries produce less than $1 \%$ of the publications in all journal percentiles (Table 3). Nevertheless, while the percentage of publications of other groups of countries has increased over the ten years, the percentage of publications of high-income countries in all five journal percentile groups has significantly decreased. Figure 2 shows the differing trends of publication for different groups of countries in the top $1 \%$ of journals.

More than $2 \%$ of low-income countries' publications are based in the top $1 \%$ of journals compared to about $1 \%$ of high-income countries' publications (see Table 5 for detailed statistics). In comparison with the world percentage, low- and high-income countries have a higher proportion of their WoS publications in the top $1 \%$ of journals while it is less for lower- and upper-middle income countries. More than $73 \%$ of high-income publications are in the top 10\%, 20\% and 50\% journals (Figure 4 and Table 5).

\section{Citing behaviour by economic group}

Based on the results, more than $80 \%$ of citations to all groups of journals are from highincome countries. In general, high-income countries cite the top $1 \%$ of journals more than other groups of journals, while other groups of countries cite the last $50 \%$ of journals more (See Table 4).

\footnotetext{
${ }^{5}$ http://data.worldbank.org/about/country-classifications
} 
Over the ten years studied, the number of citations to the top $1 \%$ of journals from highincome countries has sharply declined while upper-middle income countries have increasingly cited the top $1 \%$ of journals. The number of citations low-income and lowermiddle income countries have given to the top $1 \%$ of journals has also increased slightly (Figure 3).

In proportion to the total number of citations made by the four economic groups of countries to papers published in the examined journals, more than $8 \%$ of low-income and $7 \%$ of high-income citations are to the top $1 \%$ of journals, and more than $4 \%$ for upper- middle income and 3\% for lower-middle income countries (Figure 5 and Table 6).

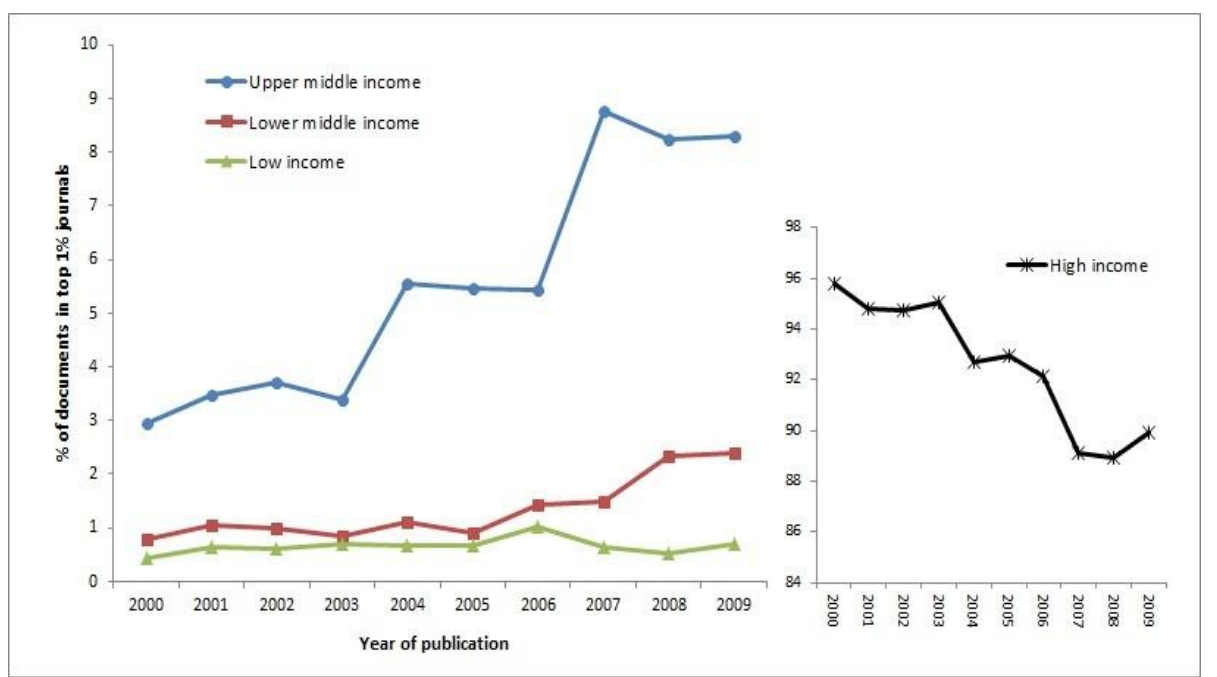

Figure 2. The share of publications in the top $1 \%$ of journals for four economic groups of countries

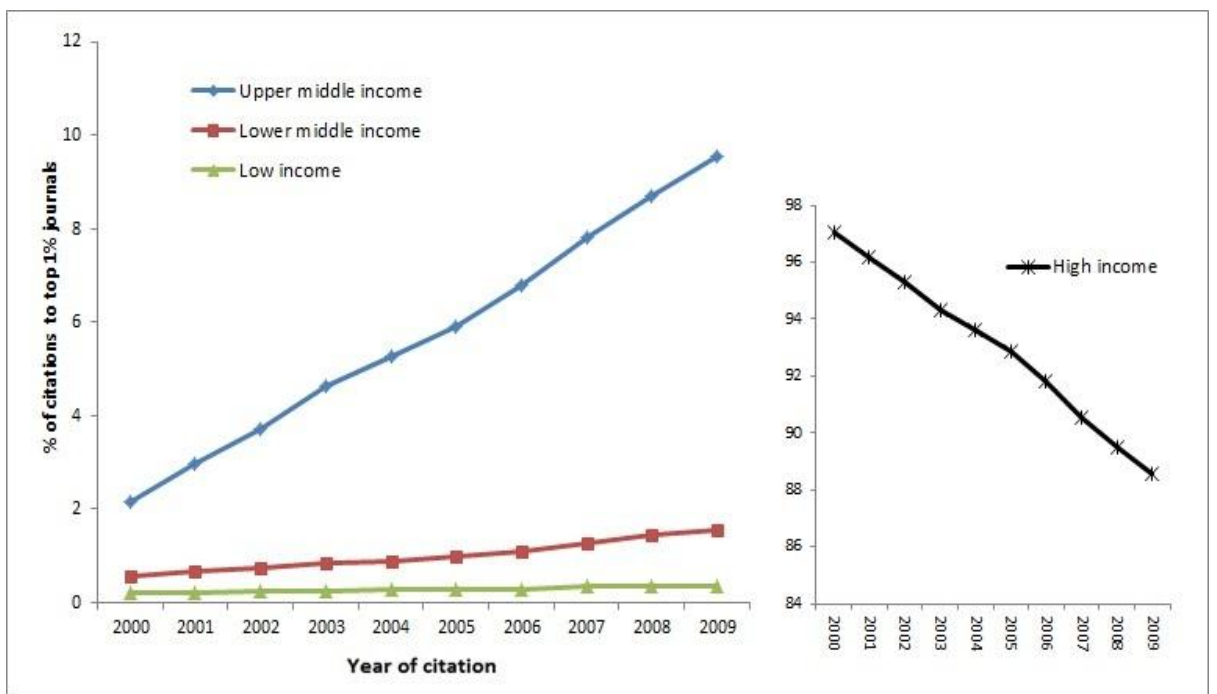

Figure 3. The share of citations to the top $1 \%$ of journals for four economic groups of countries 


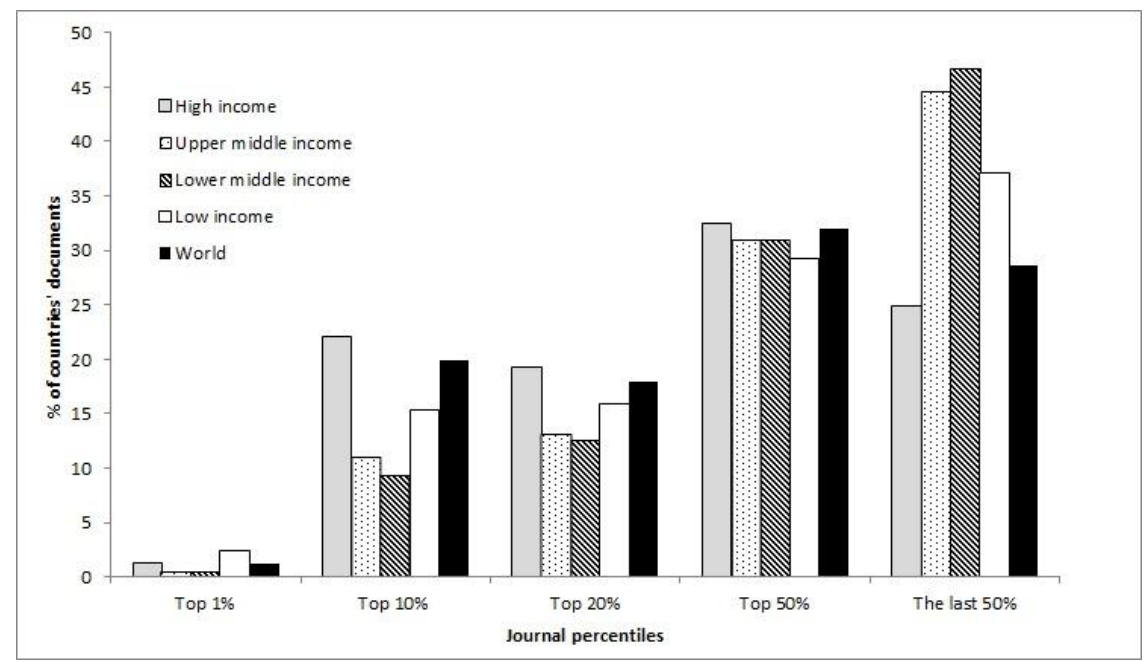

Figure 4. The share of publications in different journal percentiles in proportion to the number of publications during 2000 to 2009

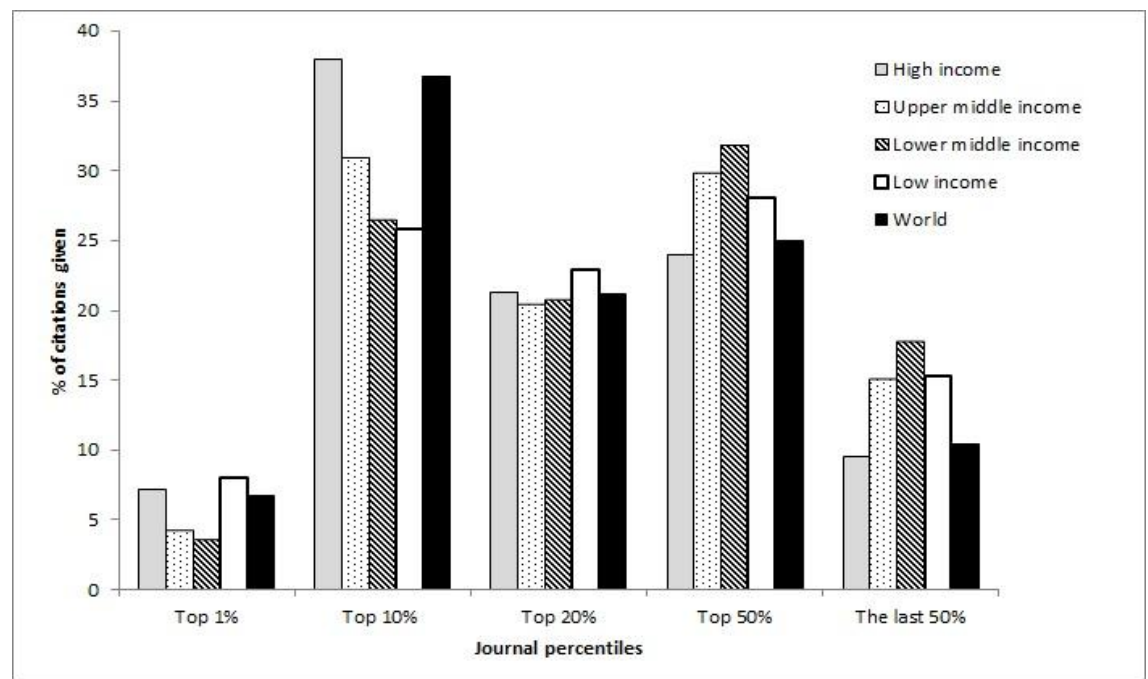

Figure 5. The share of citations given to different journal percentiles in proportion to the number of citations to those journals during 2000 to 2009

\section{Publishing behaviour by scientific group}

On average, more than $88 \%$ of publications in the top $1 \%$ of journals are by SACs and only $12 \%$ are published by the other three groups of countries (Table 7). However, the share of SAC publications in the top 1\% of journals has decreased over the years whereas this share has climbed dramatically for SPCs and gradually for SDCs and SLCs (Figure 6).

Only $1.38 \%$ of total SAC publications are in the top $1 \%$ of journals. SLCs follow with $1.05 \%$ of their total publications (Table 9). The remaining SAC publications are shared almost equally (around 20 to 30\%) in the top 10\%, 20\%, 50\%, and the last 50\% of journals. SDCs and SLCs publish almost twice as much as SACs in the last $50 \%$ of journals. World percentages are similar to those of SPCs (Figure 8 and Table 9).

\section{Citing behaviour by scientific group}

The citing behaviour of these countries is similar to their publishing behaviour: the highest percentage of total journal citations (around 75\%) is from SACs and less than $2 \%$ are from SLCs (Table 8). Moreover, while the share of SAC citations to different journal percentiles is 
decreasing, the number of citations to journals from the other groups of countries is increasing (Figure 7).

Our findings show that all SACs $(7.35 \%)$ cite the top $1 \%$ of journals twice as much as SDCs (3.42\%), and also 1.5 times more than SPCs (4.46\%) and SLCs (5.05\%) (Figure 9 and Table 10).

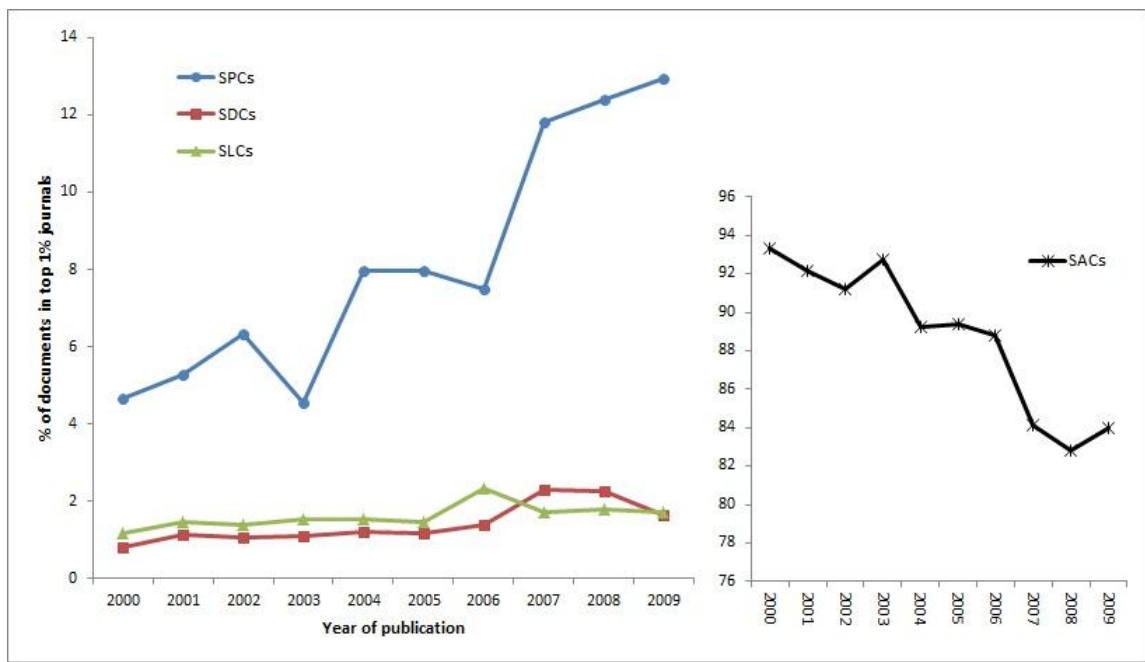

Figure 6 . The share of scientific groups of countries' total publications in the top $1 \%$ of journals

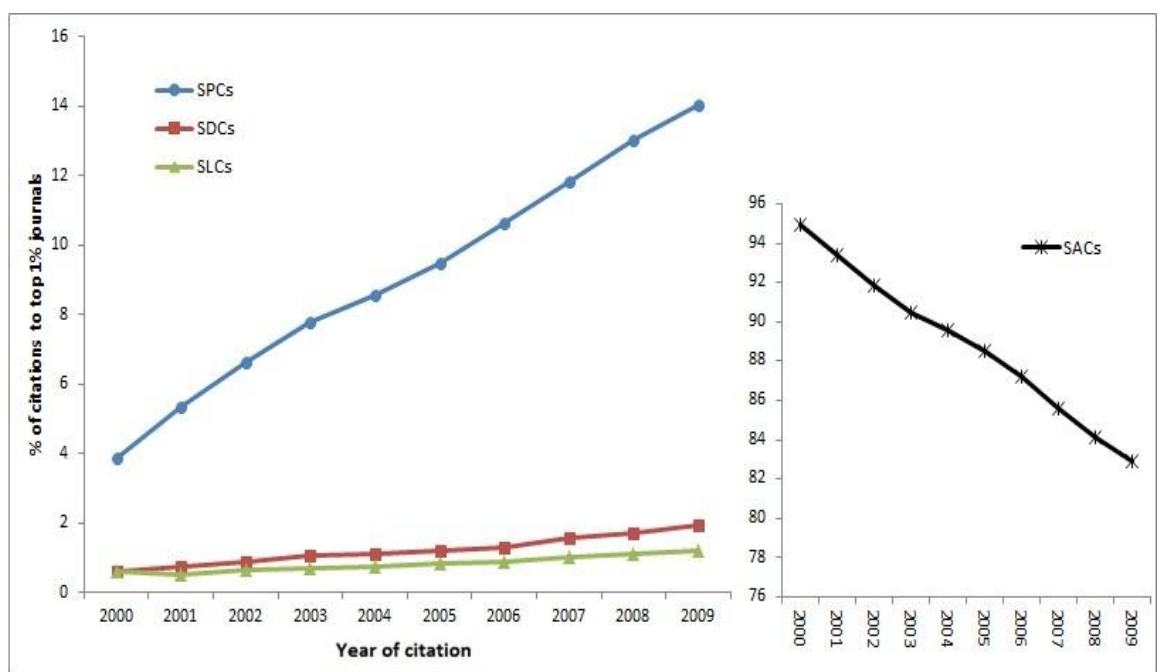

Figure 7. The share of scientific groups of countries' total citations to the top $1 \%$ of journals 


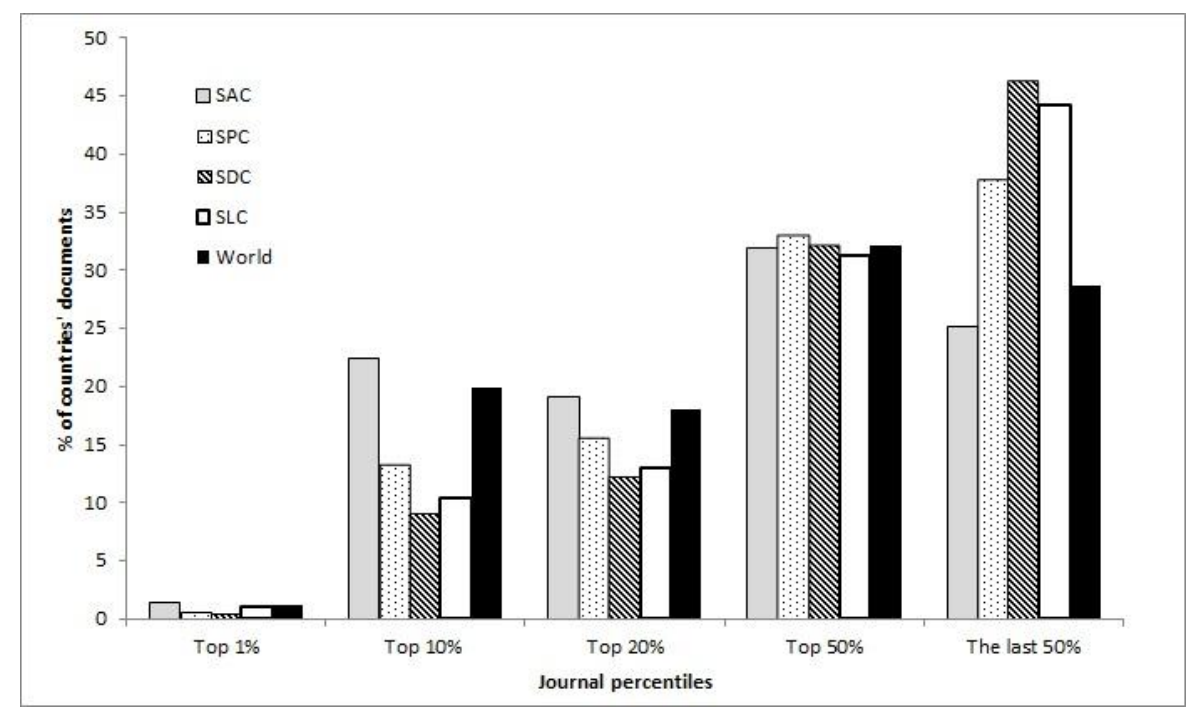

Figure 8 . The share publications in different journal percentiles in proportion to the publications during 2000 to 2009

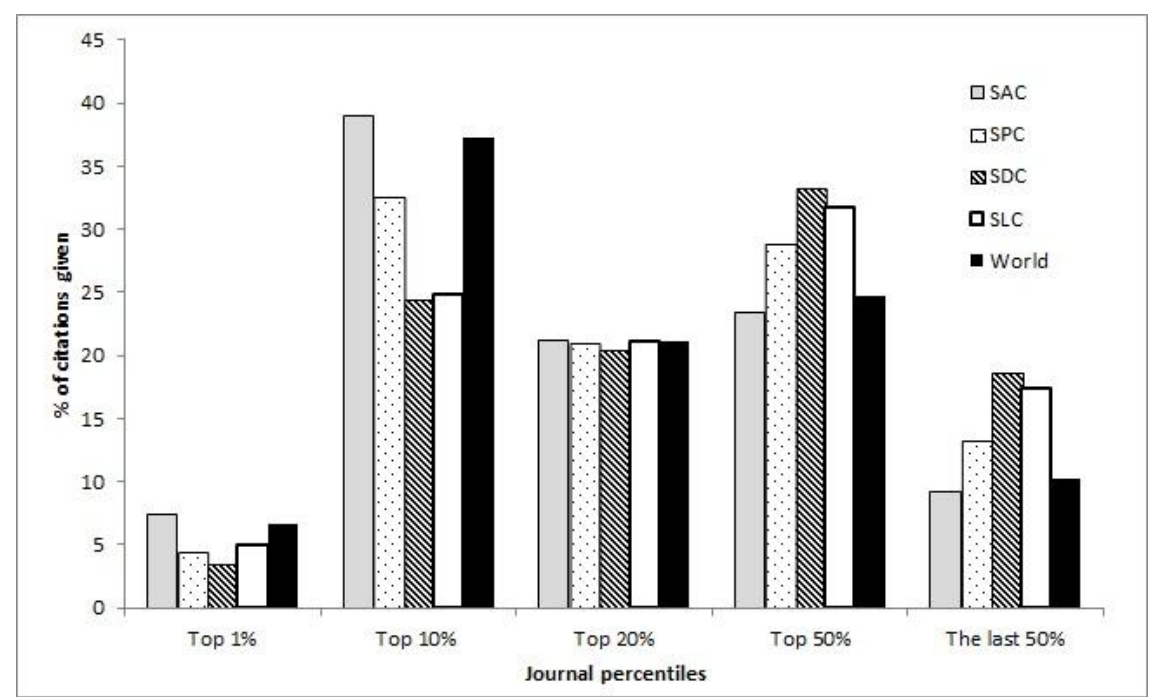

Figure 9. The share of citations given to different journal percentiles in proportion to the citations to those journals during 2000 to 2009

An important point of context is that a large number of international journals (especially the high-quality journals) belong to developed countries (Tables 11 and 12). As shown, no low- or lower-middle income countries and also no SLCs or SDCs own any journals in the top $1 \%$. More than $90 \%$ of journals in all percentiles belong to high-income countries and SACs.

\footnotetext{
Collaboration between less developed countries and developed countries and their shares

We hypothesised that disproportionately many publications of economically and scientifically less developed countries in top journals are the result of collaborations with developed countries. In fact, approximately $94 \%$ of high-income publications published in the top $1 \%, 10 \%$ and $20 \%$ of journals are the result of collaboration among two or more highincome countries or are single-high-income publications ${ }^{6}$. Furthermore, more than $80 \%$ of
}

\footnotetext{
6 "Single publications" means publications of no collaboration.
} 
low-income publications in the top $1 \%, 10 \%$ and $20 \%$ of journals are collaborations with high-income countries. The percentage of low-income-only publications in the last $50 \%$ of journals is more than in other percentiles (around 27\%).

Only $6.5 \%$ of SAC publications in the top $1 \%, 10 \%$ and $20 \%$ are collaborations with SPCs, SDCs, and SLCs and $93.5 \%$ of their publications are SAC-only. In contrast, approximately $78 \%$ of SLC publications in the top $1 \%, 10 \%$ and $20 \%$ have been published in cooperation with SACs and SPCs. Investigating SLC publications in the last $50 \%$ of journals reveals that well above $69 \%$ of SLC publications are SLC-only and only $16 \%$ of their publications have been published in collaboration with SACs.

To investigate how far international collaboration is distorting the citing and publishing patterns, the dominant group in collaboration between each pair of groups was determined. For this purpose, the share of authors of each group in collaboration with another group was calculated. As observed in collaboration between developed and less developed groups, the proportion of authors from both economically and scientifically developed groups is more than that of the less developed groups. In other words, in collaboration between a developed group with a less developed group, the share of authors of the former group is dominant but the difference is small. For instance, the share of authors of low-income countries in collaboration with high-income, upper-middle income, and lower-middle income countries is 44.6, 46.1, and 48.2, respectively. The same results were found for SLCs. High-income countries and SACs have been the major contributors in collaboration with less developed countries but the proportion of their authors is not much greater than the authors from less developed groups (Tables 13 and 14).

\section{Discussion and conclusion}

In answer to the first research question, the findings confirm that a large proportion of the publications in all international journals originate in economically and scientifically developed countries. This is despite high-income countries and SACs not having the largest total population (Table 2). More specifically over $87 \%$ and $81 \%$ of publications in the top $1 \%-50 \%$ of journals originate in high-income countries and SACs, respectively. Less than $0.5 \%$ and $1.5 \%$ of publications in the top $1 \%-50 \%$ of journals belong to low-income countries and SLCs, respectively. The low-income group has the lowest population. However, in proportion to their total publications and in comparison with the other groups in their category, low-income countries $(2.34 \%$, Table 5$)$ tend to publish a higher rate in the top $1 \%$ of journals.

In answer to the second research question, we found that countries' citing behaviour correlates with their publishing behaviour. Economically and scientifically developed countries are the main citers of journals. Furthermore, both groups cite high-quality more than lower-quality journals. Around $84 \%$ and $79 \%$ of total citations to journals are from articles published by high-income countries and SACs, respectively. Less than $0.5 \%$ and $1.5 \%$ of citations to the top $1 \%-5 \%$ of journals belong given by low-income countries and SLCs, respectively. However, in proportion to the total number of citations, low-income countries tend to cite top $1 \%$ journals more than the other three groups and SACs are citing the top $1 \%$ journals more than SPCs and SDCs. It therefore seems that less developed countries have also access to international journals and are aware of their content. So perhaps it could be concluded that although these countries generally lack access to information sources (Chan, Kirsop, \& Arunachalam, 2005; Arunachalam, 2003), their lack of access to top journals is unlikely to be greater than to the other journals. Given that ISI (Thomson Reuters) attempts to cover of the most influential journals, countries which have access to the ISI's journals probably have access to many of the top journals. 
A limitation of this study is that it only processed those references whose journals are indexed in JCR, so a number of data were lost. Indeed, ISI does not provide access to detailed information of references not indexed in its databases but actually a large number of references were found and analysed; so we believe that the results of this huge sample examined could be generalized to the whole population and it does not have a significant impact on the results found.

Moreover, although ISI databases cover many journals in different disciplines, the journals set of ISI is selective and only high prestige journals in each subject are included (Testa, 2006). This selective set of journals has definitely affected the results of our study as local journals are rarely found in the database and publishing and citing behaviours of local journals may differ from these behaviours for the most internationally influential journals. Thus, the results of the current study may not generalize to every other data sample as ISI's journals are not representative of all journals, especially local journals.

In answer to the third research question, the decreasing rate of high-income and SAC publications in all journal percentiles, particularly in the top $1 \%$ of journals, in comparison with the increasing rate of publications of other groups over the ten years examined, shows increasing progress in the acceptance rate of publications of non-high-income/non-SAC countries in the top international journals. This is important evidence of a decrease in the current sharp publishing inequalities.

There is a widely-held belief that research collaboration is very beneficial; over the last decades, policy makers in less developed countries have been aware of its benefits to their scientific community. The answer to the last question of the present study is further evidence clearly emphasising the significance of research cooperation, particularly between developed and less developed countries. Although in collaboration between developed and less developed countries the former are the major contributors, the difference is not very large. Hence the citing and publishing behaviours of groups of countries should not be affected by the behaviour of the dominant group. A large number of high-income and SAC publications in high-quality journals have been published through domestic cooperation (high-income with high-income or SACs with SACs). Moreover, the publications of less developed countries in top journals were likely to be in cooperation with developed countries. In other words, for researchers in less developed countries research cooperation is a bridge through which they can publish in the highest impact journals.

\section{References}

Amin, M. \& Mabe, M. (2000). Impact factors: Use and abuse. Perspectives in Publishing, 1, 1-6.

Arunachalam, S. (2003). Information for Research in Developing Countries - Information Technology, a Friend or Foe? International Information and Library review, 35(2-4), 133-147.

Bairam, E. I. (1994). Institutional affiliation of contributors to top economic journals, 1985-1990. Journal of Economic Literature, 32(2), 674-679.

Beaver, D. D. (2001). Reflections on scientific collaboration (and its study): past, present, and future. Scientometrics, 52(3), 365-377.

Black, N. \& Davies, S. (1999). Where do UK health services researchers publish their findings? Journal of the Royal Society of Medicine, 92, 129-131.

Boldt, J., Maleck, W., \& Koetter, K. (1999). Which countries publish in important anesthesia and critical care journals? Anesthesia and Analgesia, 88(5), 1175-1180.

Bornmann, L., Schier, H., Marx, W. \& Daniel, H-D. (2012). What factors determine citation counts of publications in chemistry besides their quality? Journal of Informetrics, 6, 11-18.

Boyack, K. W. and Klavans, R. (2005). Predicting the importance of current papers. in Ingwersen, P. and Larsen, B. (Eds), Proceedings of the 10th International Conference of the International Society for Scientometrics and Informetrics, Karolinska University Press, Stockholm. 
Brody, S. \& Foster, W. R. (1995). Impact factor as the best operational measure of medical journals. The Lancet, 346 (8985), 1300-1301.

Braun, T., Glänzel, W., \& Schubert, A. (1985). Scientometric Indicators: A 32-Country Comparative Evaluation of Publishing Performance and Citation Impact. Singapore, Philadelphia: World Scientific Publ. Co.

Buela-Casal, G. (2004). Assessing the quality of articles and scientific journals: proposal for weighted impact factr and a quality index. Psychology in Spain, 8(1), 60-76.

Campbell, F. M. (1990). National bias: a comparison of citation practices by health professionals. Bulletin of the Medical Library Association, 78, 376-382.

Campbell, P. (2008). Escape from the impact factor. Ethics in Science and Environmental Politics, 8, 5-7.

Carnegie, G. D. \& Potter, B. N. (2000). Publishing Patterns in Specialist Accounting History Journals in the English Language, 1996-1999. Accounting Historians Journal, 27(2), 177-198.

Chan, L., Kirsop, B. \& Arunachalam, S. (2005). Open Access Archiving: the fast track to building research capacity in developing countries. SciDevNet, November 2005. Available at: http://www.scidev.net/ms/openaccess.

Cheung, C. K. (2008). Audience matters: A study of how authors select educational journals. The Asia-Pacific Education Researcher, 17(2), 191-201.

Cheung, C. K. (2009). Possible biases in Educational journals: a retrospective study of five leading journals. Asia-Pacific Education Researcher, 18(1), 129-138.

Cronin, B. (2001). Hyperauthorship: A Postmodern Perversion or Evidence of a Structural Shift in Scholarly Communication Practices? Journal of the American Society for Information Science \& Technology, 52(7), 558-569.

Elliott, C., Greenaway, D., \& Sapsford, D. (1998). Who's publishing who? The national composition of contributors to some core US and European journals. European Economic Review, 42(1), 201-206.

Elster, A. D. \& Chen, M. Y. M. (1994). The internationalization of the American Journal of Roentgenology: 1980 -1992. American Journal of Roentgenol, 162, 519-522.

Faulkner, W. (1981). Indicators of National Scientific Performance. Methods, Problems and Possibilities. MSc thesis, University of Sussex.

Garfield, E. (1998). The diverse roles of citation indexes in scientific research. Revista De Investigacion Clinica, 50, 497-504.

Garfield, E. (1999). Journal impact factor: a brief review. Canadian Medical Association or its licensors, 161(8), 979-980.

Glänzel, W., \& Moed, H. F. (2002). Journal impact measures in bibliometric research. Scientometrics, 53(2), 171-194.

Gordon, M. D. (1984). How authors select journals: a test of the reward maximization model of submission behaviour. Social Studies of Science, 14, 27-43.

Gracza, T. \& Somoskovi, I. (2007). Impact factor and/or Hirsch index? Orvosi Hetilap, 148(18), 849-852.

Hansson, S. (1995). Impact Factor as a misleading tool in evaluation of medical journals. Lancet, $346,906$.

Jones, M. J. \& Roberts, R. (2005). International Publishing Patterns: An Investigation of Leading UK and US Accounting and Finance Journals. Journal of Business Finance \& Accounting, 32(5-6), 1107-1140.

Kaltenborn, K. F., \& Kuhn, K. (2004). The journal impact factor as a parameter for the evaluation of researchers and research. Revista Espanola de Enfermedades Digestivas, 96(7), 460-476.

Kim, M.-J. (2002). Citation Patterns of Korean Physicists and Engineers: Differences by Type of Publication Source and Type of Authorship. Scientometrics, 55(3), 421-436.

Kocher, M. G. \& Sutter, M. (2001). The Institutional Concentration of Authors in Top Journals of Economics During the Last Two Decades. The Economic Journal, 111(472), 405-421.

Kostoff, R. N. (1997). The principles and practices of peer review. Science and Engineering Ethics, 3, 19-34.

Kurmis, A. P. \& Kurmis, T. P. (2006). Exploring the relationship between impact factor and manuscript rejection rates in radiologic journals. Acad Radiol, 13, 77-83.

Lancaster, F. W., Lee, S.-Y. K. \& Diluvio, C. (1990). Does place of publication influence citation behaviour? Scientometrics, 19(3-4), 239-244.

Lancho-Barrantes, B. S., Guerrero-Bote, V. P., \& Moya-Anegon, F. (2010). What lies behind the averages and significance of citation indicators in different disciplines? Journal of Information Science, 36(3), 371-382.

Luukkonen, T. (1992). Is Scientists’ Behaviour Reward-Seeking? Scientometrics, 24(2), 297-319.

Mahawar, K. K., Malviya, A. \& Kumar, G. (2006). Who publishes in leading general surgical journals? The divide between the developed and developing Worlds. Asian journals of surgery, 29(3), 140-144.

Marsh, H. W., Jayasinghe, U. W., \& Bond, N. W. (2008). Improving the peer-review process for grant applications-reliability, validity, bias, and generalizability. American Psychologist, 63(3), 160-168.

Martin, B. R. (1996). The use of multiple indicators in the assessment of basic research. Scientometrics, 36, 343-362. 
Miller, T. \& Dodge, H. R. (1979). Ratings of professional journals by teachers of management. Improving College \& University Teaching, 27(3), 102-103.

Moed, H. F., \& van Leeuwen, T. N. (1996). Impact Factors can mislead. Nature, 381, 186.

Moed, H. F., van Leeuwen, T. N., \& Reedijk, J. (1996). A Critical analysis of the Journals Impact Factors of Angewandte Chemic and the Journal of the American Chemical Society: Inaccuracies in published Impact Factors based on overall citations only. Scientometrics, 37, 105-115.

Moed, H. F., van Leeuwen, T. N., \& Reedijk, J. (1999). Towards appropriate indicators of journal impact. Scientometrics, 46(3), 575-589.

Moed, H. F. (2005). Citation Analysis in Research Evaluation. New York: Kluwer Academic Publishers.

Ohniwaa, R. L., Denawaa, M., Kudob, M., Nakamurab, K., \& Takeyasua, K. (2004). Perspective factor: a novel indicator for the assessment of journal quality. Research Evaluation, 3, 175-180.

Patel, V. \& Sumathipala, A. (2001). International representation in psychiatric literature: surveys of six leading journals. British Journal of Psychiatry, 178, 406-409.

Persson, O., Glänzel, W., \& Danell, R. (2004). Inflationary bibliometric values: The role of scientific collaboration and the need for relative indicators in evaluative studies. Scientometrics, 60(3), 421-432.

Rabkin, Y. M. \& Inhaber, H. (1979). Science on the Periphery: A Citation Study of Three Less Developed Countries. Scientometrics, 1, 261-74.

Rohra, D. K. (2011). Representation of less-developed countries in Pharmacology journals: an online survey of corresponding authors. BMC Medical Research Methodology, 11, 60.

Saha, S., Saint, S., \& Christakis, D. A. (2003). Impact factor: A valid measure of journal quality? Journal of the Medical Library Association, 91(1), 42-46.

Schubert, A., Glänzel, W., \& Braun, T. (1989). Scientometric datafiles. A comprehensive set of indicators on 2649 journals and 96 countries in all major science fields and subfields 1981-1985. Scientometrics, 16(1-6), 3-478.

Schubert, A., Zsindely, S., \& Braun, T. (1989). Scientometric analysis of attendance at international scientific meetings. Scientometrics, 5(3), 177-178.

Seglen, P. O. (1997a). Why the impact factor of journals should not be used for evaluating research. BMJ, 314 (7079), 498-502.

Seglen, P. O. (1997b). Citations and Journal Impact Factors: Questionable indicators of research quality. Allergy, 52, 1050-1056.

Seglen, P. O. (1997c). Why the impact factor of journals should not be used for evaluating research. British Medical Journal, 314, 498-502.

Seglen, P. O. (1998). Citation rates and journal impact factors are not suitable for evaluation of research. ACTA Orthopaedica Scandinavica, 69, 224-229.

Shichor, D., O'Brien, R. M., \& Decker, D. L. (1981). Prestige of journals in criminology and criminal justice. Criminology, 19(3), 461-469.

Singh, D. (2006). Publication bias- a reason for the decreased research output in developing countries. South African Psychiatry Review, 9, 153-155.

Smith, L. C. (1981). Citation analysis. Library Trends, 30, 83-106.

Smith, R. (2002). Publishing research in developing countries. Statistics in Medicine, 21, 2869-2877.

Test, J. (2006). The Thomson Scientific journal selection process. International Microbiology, 9, 135-138.

The World Bank (2011). How we classify countries. Available at: http://data.worldbank.org/about/countryclassifications.

Velho, L. \& Krige, J. (1984). Publication and Citation Practices of Brazilian Agricultural Scientists. Social Studies of Science, 14 (1), 45-62.

Wagner, C. S., Brahmakulam, I., Jackson, B., Wong, A., \& Yoda, T. (2001). Science and technology collaboration: Building capacities in developing countries? Santa Monica, CA, RAND.

Whitehouse, G. H. (2001). Citation rates and impact factors: should they matter? The British Journal of Radiology, 74, 1-3.

Yue, W. P. (2004). Predicting the citation impact of clinical neurology journals using structural equation modeling with partial least squares. PhD. Dissertation. Sydney, Australia: University of New South Wales. 


\section{Appendix (Tables 3-12)}

Table 3. Percentage of publications in different percentiles of journals belonging to four economic groups of countries

\begin{tabular}{|c|c|c|c|c|c|c|c|c|}
\hline \multirow[b]{2}{*}{ Year } & \multicolumn{4}{|c|}{ High income } & \multicolumn{4}{|c|}{ Upper middle income } \\
\hline & $\begin{array}{c}\text { Top } 1 \%(\% \\
\text { of World } \\
\text { publications) }\end{array}$ & $\begin{array}{c}\text { Top } 20 \%(\% \\
\text { of World } \\
\text { publications) }\end{array}$ & $\begin{array}{c}\text { Top } 50 \%(\% \\
\text { of World } \\
\text { publications) }\end{array}$ & $\begin{array}{l}\text { The last } 50 \% \\
\text { (\% of World } \\
\text { publications) }\end{array}$ & $\begin{array}{c}\text { Top 1\% (\% } \\
\text { of World } \\
\text { publications) }\end{array}$ & $\begin{array}{c}\text { Top } 20 \%(\% \\
\text { of World } \\
\text { publications) }\end{array}$ & $\begin{array}{c}\text { Top 50\% (\% } \\
\text { of World } \\
\text { publications) }\end{array}$ & $\begin{array}{l}\text { The last } 50 \% \\
\text { (\% of World } \\
\text { publications) }\end{array}$ \\
\hline 2000 & 95.81 & 90.57 & 86.71 & 76.43 & 2.94 & 7.28 & 10.05 & 17.29 \\
\hline 2001 & 94.82 & 89.72 & 85.24 & 74.95 & 3.47 & 7.98 & 11.31 & 18.93 \\
\hline 2002 & 94.73 & 89.26 & 84.75 & 72.97 & 3.70 & 8.46 & 11.75 & 20.80 \\
\hline 2003 & 95.07 & 87.54 & 83.86 & 72.43 & 3.39 & 9.76 & 12.62 & 21.38 \\
\hline 2004 & 92.67 & 87.48 & 82.33 & 71.34 & 5.55 & 9.79 & 14.03 & 22.65 \\
\hline 2005 & 92.96 & 86.30 & 81.65 & 70.96 & 5.45 & 10.85 & 14.64 & 23.05 \\
\hline 2006 & 92.13 & 86.01 & 80.13 & 69.53 & 5.43 & 11.10 & 15.86 & 24.46 \\
\hline 2007 & 89.13 & 84.37 & 79.20 & 67.63 & 8.75 & 12.53 & 16.58 & 25.79 \\
\hline 2008 & 88.90 & 82.59 & 78.91 & 66.72 & 8.23 & 14.20 & 17.02 & 26.55 \\
\hline 2009 & 89.9 & 81.27 & 77.12 & 62.98 & 8.3 & 15.30 & 18.57 & 29.94 \\
\hline \multirow[t]{2}{*}{ Avg. } & 92.77 & 86.51 & 81.99 & 70.59 & 5.33 & 10.72 & 14.24 & 23.08 \\
\hline & \multicolumn{4}{|c|}{ Lower middle income } & \multicolumn{4}{|c|}{ Low income } \\
\hline 2000 & 0.80 & 1.91 & 2.96 & 5.88 & 0.44 & 0.25 & 0.28 & 0.41 \\
\hline 2001 & 1.06 & 2.07 & 3.17 & 5.70 & 0.65 & 0.24 & 0.28 & 0.43 \\
\hline 2002 & 0.98 & 2.07 & 3.19 & 5.83 & 0.60 & 0.21 & 0.31 & 0.40 \\
\hline 2003 & 0.85 & 2.43 & 3.25 & 5.79 & 0.69 & 0.27 & 0.27 & 0.41 \\
\hline 2004 & 1.11 & 2.45 & 3.38 & 5.57 & 0.67 & 0.29 & 0.26 & 0.44 \\
\hline 2005 & 0.90 & 2.57 & 3.43 & 5.61 & 0.68 & 0.28 & 0.29 & 0.38 \\
\hline 2006 & 1.42 & 2.59 & 3.69 & 5.61 & 0.98 & 0.30 & 0.31 & 0.40 \\
\hline 2007 & 1.49 & 2.77 & 3.90 & 6.13 & 0.63 & 0.33 & 0.32 & 0.45 \\
\hline 2008 & 2.34 & 2.88 & 3.77 & 6.28 & 0.53 & 0.32 & 0.29 & 0.45 \\
\hline 2009 & 2.4 & 3.09 & 3.98 & 6.64 & 0.69 & 0.34 & 0.33 & 0.44 \\
\hline Avg. & 1.24 & 2.48 & 3.47 & 5.90 & 0.65 & 0.28 & 0.29 & 0.42 \\
\hline
\end{tabular}

Table 4. Percentage of citations given to different percentiles of journals by four economic groups of countries

\begin{tabular}{ccccc|cccc}
\hline \multirow{4}{*}{ Year } & \multicolumn{3}{c|}{ High income } & \multicolumn{4}{c}{ Upper middle income } \\
\cline { 2 - 9 } & $\begin{array}{c}\text { Top 1\% } \\
\text { \% of World } \\
\text { citations) }\end{array}$ & $\begin{array}{c}\text { Top 20\% } \\
\text { (\% of World } \\
\text { citations) }\end{array}$ & $\begin{array}{c}\text { Top 50\% } \\
\text { (\% of World } \\
\text { citations) }\end{array}$ & $\begin{array}{c}\text { The last 50\% } \\
\text { (\% of World } \\
\text { citations) }\end{array}$ & $\begin{array}{c}\text { Top 1\% } \\
\text { \% of World } \\
\text { citations) }\end{array}$ & $\begin{array}{c}\text { Top 20\% } \\
\text { (\% of World } \\
\text { citations) }\end{array}$ & $\begin{array}{c}\text { Top 50\% } \\
(\% \text { of World } \\
\text { citations) }\end{array}$ & $\begin{array}{c}\text { The last 50\% } \\
\text { (\% of World } \\
\text { citations) }\end{array}$ \\
\hline 2000 & 97.06 & 93.92 & 91.14 & 86.35 & 2.15 & 4.66 & 6.65 & 10.61 \\
2001 & 96.19 & 92.48 & 89.73 & 84.80 & 2.95 & 5.97 & 8.22 & 12.00 \\
2002 & 95.33 & 91.39 & 88.50 & 83.86 & 3.71 & 6.89 & 9.29 & 12.81 \\
2003 & 94.31 & 90.45 & 87.33 & 82.73 & 4.61 & 7.67 & 10.21 & 13.71 \\
2004 & 93.63 & 89.52 & 86.19 & 81.78 & 5.25 & 8.49 & 11.22 & 14.63 \\
2005 & 92.86 & 88.31 & 85.10 & 80.75 & 5.90 & 9.50 & 12.11 & 15.35 \\
2006 & 91.81 & 86.80 & 83.41 & 79.44 & 6.80 & 10.75 & 13.53 & 16.48
\end{tabular}




\begin{tabular}{|c|c|c|c|c|c|c|c|c|}
\hline 2007 & 90.57 & 85.26 & 81.57 & 77.64 & 7.81 & 12.06 & 15.03 & 17.89 \\
\hline 2008 & 89.52 & 83.78 & 79.93 & 76.09 & 8.68 & 13.33 & 16.33 & 19.06 \\
\hline 2009 & 88.55 & 82.11 & 78.30 & 74.46 & 9.55 & 14.78 & 17.78 & 20.51 \\
\hline \multirow[t]{2}{*}{ Avg. } & 92.98 & 88.40 & 85.12 & 80.79 & 5.74 & 9.41 & 12.04 & 15.31 \\
\hline & \multicolumn{4}{|c|}{ Lower middle income } & \multicolumn{4}{|c|}{ Low income } \\
\hline 2000 & 0.57 & 1.19 & 2.02 & 2.71 & 0.22 & 0.23 & 0.19 & 0.33 \\
\hline 2001 & 0.67 & 1.35 & 1.84 & 2.96 & 0.19 & 0.20 & 0.20 & 0.24 \\
\hline 2002 & 0.72 & 1.53 & 2.00 & 3.04 & 0.24 & 0.19 & 0.20 & 0.29 \\
\hline 2003 & 0.84 & 1.67 & 2.21 & 3.26 & 0.24 & 0.21 & 0.25 & 0.30 \\
\hline 2004 & 0.86 & 1.77 & 2.34 & 3.28 & 0.26 & 0.23 & 0.25 & 0.31 \\
\hline 2005 & 0.97 & 1.96 & 2.55 & 3.56 & 0.26 & 0.23 & 0.24 & 0.33 \\
\hline 2006 & 1.10 & 2.18 & 2.78 & 3.73 & 0.29 & 0.27 & 0.28 & 0.36 \\
\hline 2007 & 1.28 & 2.39 & 3.11 & 4.09 & 0.33 & 0.29 & 0.29 & 0.38 \\
\hline 2008 & 1.44 & 2.58 & 3.41 & 4.44 & 0.36 & 0.31 & 0.32 & 0.40 \\
\hline 2009 & 1.55 & 2.78 & 3.59 & 4.59 & 0.34 & 0.33 & 0.34 & 0.44 \\
\hline Avg. & 1.00 & 1.94 & 2.59 & 3.57 & 0.27 & 0.25 & 0.26 & 0.34 \\
\hline
\end{tabular}

Table 5. Percentage of publications in different percentiles of journals by economic groups of countries in proportion to their total number of publications

\begin{tabular}{|c|c|c|c|c|c|c|}
\hline \multirow[b]{2}{*}{ Countries } & \multirow{2}{*}{$\begin{array}{l}\text { Total no. of } \\
\text { publications }\end{array}$} & \multicolumn{5}{|c|}{ No. and \% of publications in: } \\
\hline & & $\begin{array}{c}\text { Top 1\% } \\
\text { journals (\%) }\end{array}$ & $\begin{array}{c}\text { Top 10\% } \\
\text { journals }(\%)\end{array}$ & $\begin{array}{c}\text { Top 20\% } \\
\text { journals (\%) }\end{array}$ & $\begin{array}{c}\text { Top 50\% } \\
\text { journals }(\%) \\
\end{array}$ & $\begin{array}{c}\text { The last } 50 \% \text { of } \\
\text { journals }(\%)\end{array}$ \\
\hline High income & 8125588 & 1.34 & 22.12 & 19.22 & 32.45 & 24.87 \\
\hline Upper middle income & 1543051 & 0.43 & 10.96 & 13.16 & 30.90 & 44.55 \\
\hline Lower middle income & 368605 & 0.42 & 9.35 & 12.56 & 31.01 & 46.65 \\
\hline Low income & 32919 & 2.34 & 15.35 & 15.93 & 29.25 & 37.14 \\
\hline World & 10070163 & 1.17 & 19.87 & 17.99 & 32.05 & 28.60 \\
\hline
\end{tabular}

Table 6. Percentage of citations to different percentiles of journals by economic groups of countries in proportion to their total number of publications

\begin{tabular}{|c|c|c|c|c|c|c|}
\hline \multirow[b]{2}{*}{ Countries } & \multirow{2}{*}{$\begin{array}{c}\text { Total no. } \\
\text { of } \\
\text { citations }\end{array}$} & \multicolumn{5}{|c|}{$\%$ of citations in: } \\
\hline & & $\begin{array}{c}\text { Top 1\% } \\
\text { journals }(\%)\end{array}$ & $\begin{array}{c}\text { Top 10\% } \\
\text { journals (\%) }\end{array}$ & $\begin{array}{c}\text { Top 20\% } \\
\text { journals }(\%)\end{array}$ & $\begin{array}{c}\text { Top 50\% } \\
\text { journals }(\%)\end{array}$ & $\begin{array}{c}\text { The last } 50 \% \text { of } \\
\text { journals }(\%)\end{array}$ \\
\hline High income & 85790067 & 7.18 & 37.99 & 21.27 & 23.99 & 9.56 \\
\hline Upper middle income & 13058100 & 4.06 & 30.84 & 20.39 & 29.76 & 14.95 \\
\hline Lower middle income & 2526532 & 3.46 & 26.42 & 20.63 & 31.78 & 17.70 \\
\hline Low income & 273907 & 8.01 & 25.80 & 22.88 & 28.07 & 15.24 \\
\hline World & 101648606 & 6.69 & 36.75 & 21.15 & 24.94 & 10.47 \\
\hline
\end{tabular}

Table 7. Percentage of publications in different percentiles of journals belonging to four scientific groups of countries

\begin{tabular}{|c|c|c|c|c|c|c|c|c|}
\hline \multirow[b]{2}{*}{ Year } & \multicolumn{4}{|c|}{ SAC } & \multicolumn{4}{|c|}{ SPC } \\
\hline & $\begin{array}{c}\text { Top } 1 \% \\
\text { (\% of World } \\
\text { publications) }\end{array}$ & $\begin{array}{c}\text { Top } 20 \% \text { (\% } \\
\text { of World } \\
\text { publications) }\end{array}$ & $\begin{array}{c}\text { Top } 50 \%(\% \\
\text { of World } \\
\text { publications) }\end{array}$ & $\begin{array}{l}\text { The last } 50 \% \\
\text { (\% of World } \\
\text { publications) }\end{array}$ & $\begin{array}{c}\text { Top } 1 \% \\
\text { (\% of World } \\
\text { publications) }\end{array}$ & $\begin{array}{l}\text { Top } 20 \% \text { (\% } \\
\text { of World } \\
\text { publications) }\end{array}$ & $\begin{array}{c}\text { Top } 50 \% \text { (\% } \\
\text { of World } \\
\text { publications) }\end{array}$ & $\begin{array}{l}\text { The last } 50 \% \\
\text { (\% of World } \\
\text { publications) }\end{array}$ \\
\hline 2000 & 93.33 & 85.68 & 80.97 & 72.86 & 4.68 & 11.34 & 14.75 & 20.42 \\
\hline 2001 & 92.12 & 84.00 & 79.37 & 70.91 & 5.27 & 12.90 & 15.92 & 22.08 \\
\hline
\end{tabular}




\begin{tabular}{|c|c|c|c|c|c|c|c|c|}
\hline 2002 & 91.23 & 83.59 & 78.63 & 69.76 & 6.33 & 13.22 & 16.47 & 22.36 \\
\hline 2003 & 92.77 & 81.70 & 77.51 & 68.67 & 4.57 & 14.61 & 17.36 & 23.02 \\
\hline 2004 & 89.27 & 80.95 & 75.94 & 67.56 & 7.97 & 15.38 & 18.62 & 23.78 \\
\hline 2005 & 89.39 & 80.03 & 74.94 & 66.55 & 7.97 & 16.09 & 19.43 & 24.61 \\
\hline 2006 & 88.76 & 79.39 & 72.96 & 65.20 & 7.48 & 16.72 & 21.20 & 25.67 \\
\hline 2007 & 84.16 & 77.47 & 72.00 & 63.49 & 11.82 & 18.22 & 21.77 & 26.63 \\
\hline 2008 & 82.84 & 75.80 & 71.48 & 62.35 & 12.4 & 19.54 & 22.16 & 27.53 \\
\hline 2009 & 83.98 & 74.02 & 69.72 & 58.27 & 12.95 & 20.82 & 23.47 & 30.04 \\
\hline Avg. & 88.98 & 80.26 & 75.35 & 66.56 & 7.98 & 15.88 & 19.11 & 24.62 \\
\hline \multicolumn{5}{|c|}{ SDC } & \multicolumn{4}{|c|}{ SLC } \\
\hline 2000 & 0.83 & 1.91 & 2.83 & 4.30 & 1.16 & 1.06 & 1.45 & 2.42 \\
\hline 2001 & 1.13 & 2.12 & 3.18 & 4.56 & 1.47 & 0.99 & 1.53 & 2.45 \\
\hline 2002 & 1.05 & 2.19 & 3.36 & 5.31 & 1.39 & 0.99 & 1.54 & 2.57 \\
\hline 2003 & 1.11 & 2.50 & 3.58 & 5.63 & 1.55 & 1.19 & 1.55 & 2.69 \\
\hline 2004 & 1.21 & 2.45 & 3.82 & 6.03 & 1.55 & 1.22 & 1.61 & 2.62 \\
\hline 2005 & 1.17 & 2.61 & 3.94 & 6.24 & 1.47 & 1.26 & 1.69 & 2.59 \\
\hline 2006 & 1.41 & 2.59 & 3.99 & 6.48 & 2.34 & 1.30 & 1.85 & 2.64 \\
\hline 2007 & 2.31 & 2.83 & 4.33 & 6.90 & 1.71 & 1.47 & 1.90 & 2.97 \\
\hline 2008 & 2.27 & 3.15 & 4.37 & 7.01 & 1.81 & 1.50 & 1.99 & 3.11 \\
\hline 2009 & 1.64 & 3.39 & 4.64 & 8.21 & 1.72 & 1.77 & 2.17 & 3.48 \\
\hline Avg. & 1.41 & 2.57 & 3.80 & 6.07 & 1.62 & 1.28 & 1.73 & 2.75 \\
\hline
\end{tabular}

Table 8. Percentage of citations given to different percentiles of journals by four scientific groups of countries

\begin{tabular}{|c|c|c|c|c|c|c|c|c|}
\hline \multirow[b]{2}{*}{ Year } & \multicolumn{4}{|c|}{ SAC } & \multicolumn{4}{|c|}{ SPC } \\
\hline & $\begin{array}{l}\text { Top 1\% (\% } \\
\text { of World } \\
\text { citations) } \\
\end{array}$ & $\begin{array}{l}\text { Top 20\% (\% } \\
\text { of World } \\
\text { citations) }\end{array}$ & $\begin{array}{l}\text { Top 50\% (\% } \\
\text { of World } \\
\text { citations) }\end{array}$ & $\begin{array}{c}\text { The last } 50 \% \\
\text { (\% of World } \\
\text { citations) }\end{array}$ & $\begin{array}{l}\text { Top 1\% (\% } \\
\text { of World } \\
\text { citations) }\end{array}$ & $\begin{array}{l}\text { Top 20\% (\% } \\
\text { of World } \\
\text { citations) }\end{array}$ & $\begin{array}{l}\text { Top 50\% (\% } \\
\text { of World } \\
\text { citations) } \\
\end{array}$ & $\begin{array}{l}\text { The last } 50 \% \\
\text { (\% of World } \\
\text { citations) }\end{array}$ \\
\hline 2000 & 94.89 & 90.51 & 87.30 & 82.68 & 3.88 & 7.64 & 9.94 & 13.69 \\
\hline 2001 & 93.39 & 88.03 & 84.68 & 79.83 & 5.35 & 9.75 & 12.21 & 16.03 \\
\hline 2002 & 91.81 & 86.11 & 82.53 & 77.88 & 6.65 & 11.29 & 13.96 & 17.37 \\
\hline 2003 & 90.48 & 84.95 & 81.09 & 76.25 & 7.76 & 12.23 & 14.97 & 18.24 \\
\hline 2004 & 89.57 & 83.76 & 79.65 & 75.23 & 8.55 & 13.18 & 16.11 & 18.83 \\
\hline 2005 & 88.53 & 82.17 & 78.31 & 73.90 & 9.46 & 14.47 & 17.12 & 19.72 \\
\hline 2006 & 87.18 & 80.29 & 76.11 & 72.24 & 10.61 & 15.99 & 18.88 & 20.95 \\
\hline 2007 & 85.56 & 78.50 & 74.17 & 70.39 & 11.83 & 17.31 & 20.11 & 22.00 \\
\hline 2008 & 84.13 & 76.85 & 72.27 & 68.55 & 13.01 & 18.48 & 21.47 & 23.28 \\
\hline 2009 & 82.87 & 74.91 & 70.49 & 66.80 & 14.01 & 19.86 & 22.61 & 24.28 \\
\hline \multirow[t]{2}{*}{ Avg. } & 88.84 & 82.61 & 78.66 & 74.38 & 9.11 & 14.02 & 16.74 & 19.44 \\
\hline & \multicolumn{4}{|c|}{ SDC } & \multicolumn{4}{|c|}{ SLC } \\
\hline 2000 & 0.62 & 1.16 & 1.73 & 2.37 & 0.60 & 0.69 & 1.03 & 1.26 \\
\hline 2001 & 0.74 & 1.51 & 2.09 & 2.81 & 0.52 & 0.70 & 1.01 & 1.33 \\
\hline 2002 & 0.90 & 1.79 & 2.46 & 3.33 & 0.65 & 0.81 & 1.04 & 1.42 \\
\hline 2003 & 1.06 & 1.96 & 2.77 & 3.89 & 0.71 & 0.86 & 1.17 & 1.62 \\
\hline 2004 & 1.11 & 2.14 & 3.01 & 4.24 & 0.76 & 0.92 & 1.23 & 1.71 \\
\hline 2005 & 1.20 & 2.35 & 3.27 & 4.57 & 0.82 & 1.01 & 1.30 & 1.81 \\
\hline 2006 & 1.30 & 2.54 & 3.53 & 4.85 & 0.90 & 1.18 & 1.48 & 1.96 \\
\hline 2007 & 1.59 & 2.90 & 4.07 & 5.46 & 1.02 & 1.29 & 1.66 & 2.16 \\
\hline
\end{tabular}




\begin{tabular}{lllll|lllll}
2008 & 1.73 & 3.20 & 4.37 & 5.75 & 1.13 & 1.47 & 1.89 & 2.41 \\
2009 & 1.93 & 3.55 & 4.81 & 6.26 & 1.19 & 1.67 & 2.09 & 2.66 \\
\hline Avg. & 1.22 & 2.31 & 3.21 & 4.35 & 0.83 & 1.06 & 1.39 & 1.83 \\
\hline
\end{tabular}

Table 9. Percentage of publications in different percentiles of journals by different scientific groups of countries in proportion to their total number of publications

\begin{tabular}{rcccccc}
\hline \multirow{2}{*}{ Countries } & Total no. of & \multicolumn{5}{c}{ \% of publications in: } \\
\cline { 3 - 7 } & publications & $\begin{array}{c}\text { Top 1\% } \\
\text { journals (\%) }\end{array}$ & $\begin{array}{c}\text { Top 10\% } \\
\text { journals (\%) }\end{array}$ & $\begin{array}{c}\text { Top 20\% } \\
\text { journals (\%) }\end{array}$ & $\begin{array}{c}\text { Top 50\% } \\
\text { journals (\%) }\end{array}$ & $\begin{array}{c}\text { The last 50\% of } \\
\text { journals (\%) }\end{array}$ \\
\hline SAC & $\mathbf{7 5 5 0 1 2 6}$ & 1.38 & 22.43 & 19.12 & 31.95 & 25.11 \\
SPC & $\mathbf{1 9 2 1 0 8 3}$ & 0.52 & 13.27 & 15.49 & 33.00 & 37.73 \\
SDC & $\mathbf{3 9 2 1 3 7}$ & 0.45 & 9.01 & 12.27 & 32.12 & 46.15 \\
SLC & $\mathbf{1 8 2 7 5 4}$ & 1.05 & 10.34 & 13.06 & 31.28 & 44.27 \\
World & $\mathbf{1 0 0 4 6 1 0 0}$ & 1.17 & 19.94 & 18.05 & 32.15 & 28.70 \\
\hline
\end{tabular}

Table 10. Percentage of citations to different percentiles of journals by different scientific groups of countries in proportion to their total number of publications

\begin{tabular}{ccccccc}
\hline \multirow{2}{*}{ Countries } & \multirow{2}{*}{$\begin{array}{c}\text { Total no. } \\
\text { of } \\
\text { citations }\end{array}$} & $\begin{array}{c}\text { Top 1\% } \\
\text { journals (\%) }\end{array}$ & $\begin{array}{c}\text { Top 10\% } \\
\text { journals (\%) }\end{array}$ & $\begin{array}{c}\text { Top 20\% } \\
\text { journals (\%) }\end{array}$ & $\begin{array}{c}\text { Top 50\% } \\
\text { journals (\%) }\end{array}$ & $\begin{array}{c}\text { The last 50\% of } \\
\text { journals }(\%)\end{array}$ \\
\hline SAC & $\mathbf{6 6 3 6 8 4 9 8}$ & 7.35 & 38.92 & 21.19 & 23.38 & 9.17 \\
SPC & $\mathbf{1 4 1 7 1 0 2 4}$ & 4.46 & 32.55 & 20.95 & 28.75 & 13.29 \\
SDC & $\mathbf{2 4 5 6 3 5 6}$ & 3.42 & 24.37 & 20.46 & 33.16 & 18.59 \\
SLC & $\mathbf{1 0 8 6 3 8 3}$ & 5.05 & 24.82 & 21.06 & 31.73 & 17.34 \\
World & $\mathbf{8 4 0 8 2 2 6 1}$ & 6.72 & 37.24 & 21.12 & 24.68 & 10.24 \\
\hline
\end{tabular}

Table 11. Percentage of journals published by the four economic groups of countries

\begin{tabular}{|c|c|c|c|c|c|c|c|c|c|c|}
\hline Countries & 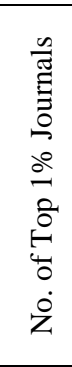 & 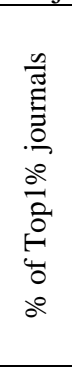 & 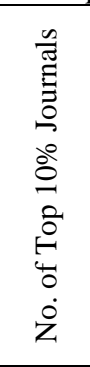 & 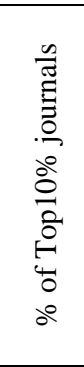 & 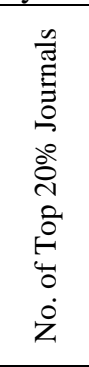 & 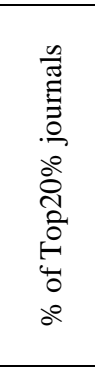 & 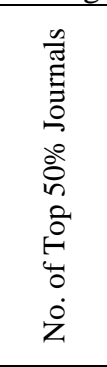 & $\begin{array}{l}\frac{0}{\pi} \\
\stackrel{\Xi}{\Xi} \\
.0 \\
0 \\
0 \\
0 \\
0 \\
0 \\
0 \\
0 \\
0 \\
0 \\
0\end{array}$ & 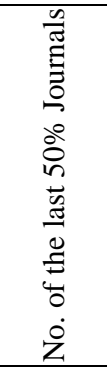 & 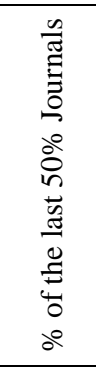 \\
\hline High-income & 874 & 100 & 6811 & 99.9 & 7508 & 99.51 & 22270 & 98.87 & 33717 & 90.63 \\
\hline Low-income & 0 & 0 & 0 & 0 & 0 & 0 & 2 & 0.01 & 96 & 0.26 \\
\hline Lower-middle income & 0 & 0 & 2 & 0.03 & 3 & 0.04 & 31 & 0.14 & 684 & 1.84 \\
\hline Upper-middle income & 0 & 0 & 5 & 0.07 & 34 & 0.45 & 222 & 0.99 & 2707 & 7.28 \\
\hline Total & 874 & 100 & 6818 & 100 & 7545 & 100 & 22525 & 100 & 37204 & 100 \\
\hline
\end{tabular}


Table 12. Percentage of journals published by the four scientific groups of countries

\begin{tabular}{|c|c|c|c|c|c|c|c|c|c|c|}
\hline Countries & 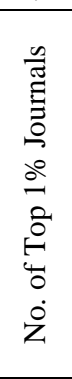 & 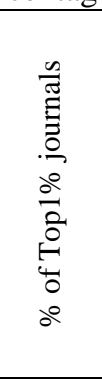 & 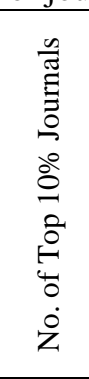 & 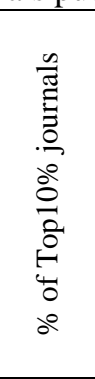 & 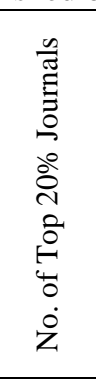 & 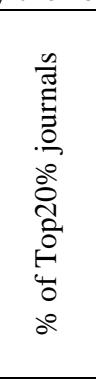 & 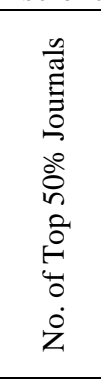 & 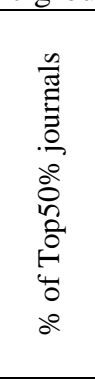 &  & 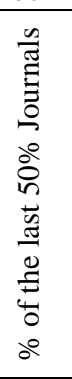 \\
\hline SACs & 873 & 99.89 & 6779 & 99.43 & 7470 & 99.02 & 22008 & 97.67 & 33479 & 89.8 \\
\hline SDCs & 0 & 0 & 2 & 0.03 & 0 & 0 & 29 & 0.13 & 582 & 1.56 \\
\hline SLCs & 0 & 0 & 0 & 0 & 4 & 0.05 & 14 & 0.06 & 184 & 0.49 \\
\hline SPCs & 1 & 0.11 & 37 & 0.54 & 70 & 0.93 & 482 & 2.14 & 3038 & 8.15 \\
\hline Total & 874 & 100 & 6818 & 100 & 7544 & 100 & 22533 & 100 & 37283 & 100 \\
\hline
\end{tabular}

Table 13. Percentage of authors of economic groups of countries in collaboration with each other

\begin{tabular}{lc|c|c|c} 
& \multicolumn{4}{c}{ Share \% of collaboration } \\
\hline \multirow{2}{*}{ Groups } & $\begin{array}{c}\text { High } \\
\text { income }\end{array}$ & $\begin{array}{c}\text { Upper } \\
\text { middle } \\
\text { income }\end{array}$ & $\begin{array}{c}\text { Lower } \\
\text { middle } \\
\text { income }\end{array}$ & $\begin{array}{c}\text { Low } \\
\text { income }\end{array}$ \\
\hline $\begin{array}{l}\text { High income* } \\
\text { Upper middle income }\end{array}$ & 42.4 & 57.6 & 56.2 & 55.4 \\
\cline { 2 - 5 } $\begin{array}{l}\text { Lower middle income } \\
\text { Low income }\end{array}$ & 43.8 & 48.5 & 51.5 & 53.9 \\
\cline { 2 - 5 } & 44.6 & 46.1 & 48.2 & 51.8 \\
\hline
\end{tabular}

* e.g. share $\%$ of high-income authors in collaboration with upper-middle,

lower-middle and low-income countries is 57.6, 56.2, and 55.4, respectively.

Table 14. Percentage of authors of scientific groups of countries in collaboration with each other Share $\%$ of collaboration

\begin{tabular}{lc|c|c|c}
\hline Groups & SAC & SPC & SDC & SLC \\
\hline SAC & & 56.3 & 59.4 & 57.4 \\
\cline { 2 - 5 } SPC & 43.7 & & 52.9 & 55.5 \\
SDC & 40.6 & 47.1 & & 52.3 \\
SLC & 42.6 & 44.5 & 47.7 & \\
\hline
\end{tabular}

